\title{
Improvement of colitis preventive effects of Gochujang by addition of Lactobacillus plantarum on C57BL/6 mice
}

\author{
Eui-Seong Park ${ }^{1}, \mathrm{Ju}^{-\mathrm{Hee}} \mathrm{Heo}^{2}$, Yaung-Iee $\mathrm{Lim}^{3}$, Jaehyun $\mathrm{Ju}^{4}$, \\ Kun-Young Park ${ }^{4 *}$ \\ ${ }^{1}$ Department of Food and Nutrition, College of Human Ecology, Yonsei University, Seoul 03772, Korea \\ ${ }^{2}$ Microbial Institute for Fermentation Industry, Sunchang 56048, Korea \\ ${ }^{3}$ Department of Food and Nutrition, Sungshin Women's University, Seoul 01133, Korea \\ ${ }^{4}$ Department of Food Science and Biotechnology, Cha University, Sungnam 13488, Korea
}

\section{Lactobacillus plantarum 첨가 고추장의 C57BL/6 마우스에서 대장염 예방 증진효과}

\author{
박의성 ${ }^{1} \cdot$ 허주희 $^{2} \cdot$ 임양이 $^{3}$. 주재현 ${ }^{4} \cdot$ 박건영 $^{4 *}$ \\ ${ }^{1}$ 연세대학교 식품영양학과, ${ }^{2}$ 발효미생물산업진흥원, \\ ${ }^{3}$ 성신여자대학교 식품영양학과, ${ }^{4}$ 차의과학대학교 식품생명공학과
}

\begin{abstract}
Gochujang, a traditional Korean food, is fermented by mixing red pepper powder, various grain, meju and salt. Changes in the kind of ingredients and fermentation method could increase health functionalities. In this study, in vivo anti-colitis effects of gochujang prepared with mixed grains, bamboo salt baked 3 times and meju starters on DSS-induced colitis in C57BL/6 mice were studied. We prepared gochujang prepared with mixed grains (MG), bamboo salt, and Aspergillus oryzae (A) and Baccillus subtilis (B) mixed starters (MG-AB) and gochujang prepared with MG, bamboo salt and A, B and Lactobacillus plantarum (L) mixed starters (MG-ABL). MG-AB and MG-ABL significantly increased body weight and colon length compared to the control $(p<0.05)$. MG-ABL showed significantly decreased interleukin-6 (IL-6) expression in serum compared to the control and MG-AB group $(p<0.05)$. MG-ABL also regulated mRNA and protein levels of pro-apoptotic Bcl-2-associated $\mathrm{X}$ protein (Bax) and anti-apoptotic B-cell lymphoma-2 (Bcl-2) in the mice colon tissue $(\mathbf{p}<0.05)$. Therefore, MG-ABL exhibited the increased anticolitis effects by inhibiting damage of colon tissue, probably by regulating a pro-inflammatory cytokine of IL-6 and regulated apoptosis related genes. These results indicated that gochujang changed with good ingredients and starters had colitis preventive effects and might be due to active compounds in mixed grain and bamboo salt, and produced by $L$ during the fermentation of gochujang.
\end{abstract}

Key words : Gochujang, Lactobacillus plantarum, dextran sulfate sodium (DSS), colitis, C57BL/6 mice

서 론

*Corresponding author. E-mail : kunypark@cha.ac.kr

Phone : 82-31-881-7159, Fax : 82-31-881-7219

Received 20 November 2017; Revised 7 December 2017;

Accepted 8 December 2017.

Copyright (c) The Korean Society of Food Preservation. All rights reserved.
고추장은 한국의 대표적인 전통발효식품으로 고춧가루, 곡류, 찹쌀, 메주, 소금 등을 이용하여 발효시킨다(1). 발효 가 되면 탄수화물의 가수분해로 생긴 단맛과 콩에서 유래한 아미노산의 감칠맛, 고추의 매운맛, 소금의 짠맛으로 인해 단맛, 감칠맛, 매운맛, 짠맛이 조화를 이루어 고추장 특유의 맛이 나타나며 이로 인해 한국인이 선호하는 발효식품이자 조미료로써 사용된다(2). 또한 고추장은 건강기능면에서 항비만(3,4), 항돌연변이(5), 항암(4), 항산화(6) 등의 효과를 
가지는 것으로도 알려져 있다. 고추장을 발효할 때 사용하 는 전분질은 일반적으로 찹쌀(7), 밀가루(8)를 이용하여 제 조한다. 또한 사용되는 소금의 종류에 따라서 고추장의 기 능성에 차이가 나타났다(9). 고추장 발효 시에는 자연발효 나 종균(A, B)을 이용 하는데, 고추장에 첨가하는 메주를 발효시키는 방법에 따라 메주 내 효모와 젖산균 등의 발효 작용으로 각종 향미, 향기, 색깔이 달라지는 것으로 보고되 어 있다(1).

본 연구에서는 건강기능성이 높은 잡곡(보리, 수수, 기 장)과 죽염을 사용하고, 고추장 발효에 참여하는 대표적인 종균 Aspergillus oryzae(A), Bacillus subtilis(B), Lactobacillus plantarum(L)을 접종한 메주를 이용하여 고추장을 담구었 다. 사용되는 잡곡 중 보리는 흰쥐에서 dextran sulfate sodium(DSS)로 유도한 대장염을 억제하는 것으로 보고되 었고(10), 수수 추출물은 항산화 및 항염증 효과가 있는 것으로 알려져 있다(11). 또한 기장은 다른 곡물에 비해 폴리페놀의 함량이 풍부하여 높은 항산화 효과를 나타내는 것으로 보고된 바 있다(12). 죽염은 우리나라의 전통방법으 로 가공한 소금으로 정제염과 천일염에 비해 항산화(13), 항암(14)효과가 뛰어난 것으로 보고되어 있다. 메주는 전통 적인 방법으로 담는 메주와 개량된 방식으로 종균를 접종하 여 메주를 담는 방법이 있는데(1), $\mathrm{A}$ 와 B 같은 종균을 접종 하여 메주를 제조하면 다른 잡균의 생성을 억제하고 이 균들이 우점종이 되어 메주의 품질이 향상되고, 고추장의 항산화 및 항암 효과도 증가하는 결과를 보인 바 있다(15). 그리고 A, B 및 Lactococcus lactis 종균을 접종하여 메주를 제조하면 기존 전통적인 메주에 비해 높은 항암 효과를 나타내는 것으로 나타났다(16). 본 연구에서 종균(A, B, L) 으로 접종한 균 중 김치에서 분리된 Lactobacillus plantarum(L)은 항산화(17), 항암효과(18)가 뛰어난 것으로 보고되어 잡곡과 죽염, $\mathrm{L}$ 이 첨가된 메주로 담은 고추장이 기존의 고추장에 비해 더 높은 항염증 효과를 나타낼 것으 로 기대되었다. 또한 이전 연구에서 잡곡(보리, 수수, 기장) 과 죽염, 종균 $(\mathrm{A}, \mathrm{B}, \mathrm{L})$ 을 접종한 메주로 담은 고추장은 일반적인 찹쌀과 천일염, 종균이 접종되지 않은 메주가루 를 이용한 고추장에 비해 품질(수분함량, $\mathrm{pH}$, 아미노태, 색도)은 차이가 없으며, 관능적으로 더욱 맛이 우수한 것으 로 나타나(19) 실제 상품으로써의 가치도 충분한 것으로 생각된다(19).

지금까지의 고추장 연구는 항비만(3), 항암(4), 항산화(6) 를 중심으로 연구가 진행되었으나, 항염증, 특히 in $v i v o$ 에 서 대장염에 대한 연구는 거의 없다. 따라서 본 연구는 DSS 로 대장염을 유도한 마우스에게 잡곡과 죽염, 종균을 접종 시킨 고추장을 섭취시킨 후, 마우스의 체중, 대장의 길이, pro-inflammatory cytokine인 interleukin-6(IL-6), apoptosis 관련 인자인 Bcl-2-associated X protein(Bax), B-cell lymphoma2(Bcl-2)의 발현을 조사하여 발효 시 $\mathrm{L}$ 첨가에 의해 대장염
억제 효과가 더욱 증진되는지를 살펴보았다.

\section{재료 및 방법}

\section{실험 재료 및 제조}

본 연구에서는 2015년산 유기농보리, 유기농수수 유기농 기장과 엿기름은 (주초록마을(Seoul, Korea, http://www. choroc.com/)에서 주문, 구입하였다. 죽염은 9번 구운 죽염 으로 (주)인산가(Hamyang, Korea)에서 제 공받아 실험에 이 용하였다. 고춧가루(Yeonggwang red pepper powder, Haesnimma-eul, Yeonggwang, Korea)는 L-마트(Busan, Korea)에서 고추장용 고운 고춧가루로 구매하였다. 메주는 메주콩을 12 시간 동안 침지한 후 $121^{\circ} \mathrm{C}$ 에서 30 분 동안 삶은 다음 $50-60^{\circ} \mathrm{C}$ 가 될 때까지 식힌 다음, 식은 콩에 $\mathrm{A}$, $0.2 \%(15), \mathrm{B}, 10^{6} \mathrm{CFU} / \mathrm{g}(15)$ 을 혼합하고 $30^{\circ} \mathrm{C}$ 에서 48 시간 동안 발효시켰다. 발효된 콩에 $\mathrm{L}, 10^{6} \mathrm{CFU} / \mathrm{g}(20)$ 을 혼합한 후 $37^{\circ} \mathrm{C}$ 에서 24 시간 동안 발효시켜 메주를 제조하고, 메주 는 동결건조 후 분말화시켜 고추장 제조 및 발효에 사용하 였다. 잡곡(보리, 수수, 기장)과 메주를 이용한 고추장 제조 는 Park 등(19)의 방법으로 제조하였다.

\section{실험동물 준비}

C57BL/6 마우스(6 week old, Samtaco Bio Korea, Osan, Korea)는 12시간 dark-light cycle로 조절한 실험실 내에 설 치한 micro ventilation cage system(온도 $23 \pm 2{ }^{\circ} \mathrm{C}$, 습도 $50 \pm 5 \%$ ) 내에서 물과 사료는 충분한 양을 공급하여 사육하 였다. 1주일간 표준사료(SAM \#3 mouse diet, Samtaco, Osan, Korea)로 사육하여 적응시킨 후 무게를 측정하고 임의로 각 군당 10 마리씩 나누어서 정상군(normal), 대조군 (control), $\mathrm{MG}-\mathrm{AB}$ 군(잡곡, 죽염, $\mathrm{A}, \mathrm{B}$ )로 발효시킨 메주를 이용한 고추장), MG-ABL군(잡곡, 죽염, $\mathrm{A}, \mathrm{B}, \mathrm{L}$ ) 발효시킨 메주를 이용한 고추장)군으로 구성하여 실험을 진행하였 다. 본 실험은 부산대학교 동물윤리위원회의 허가를 받은 후 진행하였다(승인번호: PNU-2013-0455).

\section{시료의 투여 및 대장염 유발}

모든 마우스는 실험기간 동안 표준사료를 공급하였으며, 시험 시작일 부터 2 주 동안 고추장 섭취군은 무게를 기준으 로 $4 \mathrm{~g} / \mathrm{kg}$ 의 농도로 phosphate buffer saline(PBS)에 희석하여 경구투여로 공급하였고, normal과 control군은 PBS만 공급 하였다. 대장염 유발은 $2.5 \%$ dextran sulfate sodium salt(DSS)(Reagent grade, MW. 36,000-50,000, MP Biomedicals, LLC, Illkirch, France)를 음수에 타서 2주 차에 1주간 마우스 에게 투여한 후 희생하였다(21). 마우스를 희생한 후 대장을 적출하여 길이와 무게를 측정하고, 혈액은 채취 후 원심분 리(3,000 rpm, $15 \mathrm{~min})$ 한 다음, serum을 채취하고 각각 $-80^{\circ} \mathrm{C}$ 
에 보관하여 실험에 이용하였다.

$\mathrm{IL}-6$ 분석

효소 면역 측정법(ELISA MAX Deluxe Sets, Biolegend, San Diego, CA, USA)을 이용하여 마우스 혈청의 IL-6의 양을 측정하였다. 자세한 실험방법은 제조사의 프로토콜에 따라 진행하였다(4).

\section{Apoptosis 관련 인자 분석}

RT-PCR을 이용한 Bax, Bcl-2의 mRNA 발현 분석: 각 군의 대장조직을 trizol reagent(Invitrogen Co., Carlsbad, CA, $\mathrm{USA}$ )을 이용하여 RNA를 분리하였다. 이후 RNA를 정량한 뒤 Oligo dT primer(Invitrogen Co.)를 이용하여 $2 \mu \mathrm{g}$ 의 RNA 를 ssRNA를 만들고, reverse transcription(역전사)하여 $\mathrm{cDNA}$ 로 만들었다. 만들어진 $\mathrm{cDNA}$ 를 주형으로 이용하여 $\mathrm{Bax}, \mathrm{Bcl}-2$ 유전자를 polymerase chain reaction(PCR) 방법으 로 특정 유전자 부위를 증폭하였다. 각 유전자의 발현 정도 는 housekeeping 유전자인 glyceral dehyde-3- phosphate dehydrogenase(GAPDH)를 이용하여 비교하였고, 각 유전 자의 primer sequence는 Bax; F:5'-AAGCTGAGCGAGT GTCTCCGGCG-3', R:5'-CAGATGCCGGTTCAGGTACTC AGTC-3', Bcl-2; F:5'-CAGCTGCACCTGACG-3', R:5'-GCT GGGTAGGTGCAT-3', GAPDH; F:5'-TGACGCTGGACC AATCAG-3', R:5'-ACCTCATTGGACTGCATAGC-3'이다. PCR은 Automatic Bioneer Thermocycler(Bioneer, Daejeon, Korea)로 증폭시키고, 증폭된 DNA 산물들을 $2 \%$ agarose gel을 이용하여 전기영 동하고 ethidium bromide(Sigma, St. Louis, MO, USA)를 이용하여 염색한 후 UV하에서 확인하 였다(15). 발현된 mRNA는 Image J(https://imagej.nih.gov/ij/) 프로그램을 이용하여 GAPDH와 발현양을 비교하여 정량 하였다.

Western blot을 이용한 $\mathrm{Bax}, \mathrm{Bcl}-2$ 의 단백질 발현 분석 각 군의 대장 조직을 RIPA buffer(Sigma Aldrich)에 용해 시킨 후, $12,000 \mathrm{rpm}$ 에서 15 분간 원심분리 하여 상층액에 있는 단백질을 분리하였다. 단백질을 bradford assay를 통해 정 량한 다음 동량의 Laemmli sample buffer(Bio-Rad)와 혼 합한 후 $85^{\circ} \mathrm{C}$ 에서 5 분간 반응시켰다. SDS-polyacrylamide gel 전기영동으로 분리한 후, transfer buffer를 이용하여 nitrocellulose membrane(Bio-Rad)으로 이동시켰다. Membrane 은 $10 \%$ skim milk에 $4^{\circ} \mathrm{C}$ 에서 over night 시키고 PBS-T로 세척하였다. 이후 $\mathrm{Bax}, \mathrm{Bcl}-2$, actin(Santa Cruz Biotechnology, Inc., Dallas, TX, USA)의 1 차 항체를 처리하여 $4^{\circ} \mathrm{C}$ 에서 overnight 시킨 다음 PBS-T로 세척하고, 처리된 1차 항체에 맞는 2차 항체(Santa Cruz Biotechnology, Inc.)를 사용하여 상온에서 45 분간 반응시킨 후 PBS-T로 세척하였다. 세척 후 Ez West Lumi(ATTO Co., Tokyo, Japan)을 처리한 다음
X-ray film에 감광시켜 $\mathrm{Bax}, \mathrm{Bcl}-2$, actin단백질의 발현을 측정하였다(15). 발현된 단백질은 Image J(https://imagej. nih.gov/ji/) 프로그램을 이용하여 actin과 발현양을 비교하 여 정 량하였다.

\section{통계처리}

대조군과 각 시료로부터 얻은 실험 결과들의 유의성을 검정하기 위하여 분산분석을 행한 후 $\mathrm{p}<0.05$ 수준에서 Duncan's multiple range test를 실시하였으며, 결과는 평균 (Mean)표푼편차(standard deviation, SD)로 표시하였다. 모 든 통계 분석은 SPSS(v18.0 SPSS Inc, Chicago, IL, USA) 통계프로그램을 이용하여 분석하였고, $\mathrm{p}$ 값은 $5 \%$ 미만일 때 유의성이 있다고 판정하였다.

\section{결과 및 고찰}

마우스의 체중, 대장길이 및 무게/대장길이 비율

실험 시작 시 마우스 각 군간의 체중은 유의적인 차이가 나타나지 않았다. 실험 종료일에 마우스의 무게를 관찰한 결과(Table 1) normal 군은 $20.4 \pm 1.0 \mathrm{~g}$ 으로 가장 높은 수치를 나타내었고, control군은 $17.1 \pm 2.5 \mathrm{~g}$ 으로 normal군에 비해 유의적으로 감소하였다( $\mathrm{p}<0.05)$. 그러나 MG-AB군은 19.3 $\pm 0.4 \mathrm{~g}, \mathrm{MG}-\mathrm{ABL}$ 군은 $19.2 \pm 0.4 \mathrm{~g}$ 으로 고추장을 투여한 각 군의 체중은 normal군과 유사하게 나타났다. Aliakbarpour 등(22)의 연구에 의하면 378일 된 닭에게 Bacillus subtilis와 lactic acid bacteria가 혼합된 사료를 섭취하게 했을 때, 먹이 를 섭취한 양은 같았으나, 미생물을 넣은 사료를 먹은 군의 체중이 증가하고, 대장의 goblet cell의 숫자 증가, villus의 길이가 증가한 것으로 나타났다. 따라서 고추장을 투여한 군은 고추장에 첨가된 $\mathrm{B}$ 와 $\mathrm{L}$ 에 의해 장에서 영양소의 섭취 율을 증가시키고, intestinal mucosal cell의 증식을 촉진하여 control군에 비해 체중이 증가된 것으로 생각된다.

대장의 길이는 normal군은 $7.5 \pm 0.4 \mathrm{~cm}$ 이고 control군은 $5.4 \pm 0.5 \mathrm{~cm}$ 로, 대장의 길이가 유의적으로 짧아져 DSS로 대장염이 유도된 것을 확인하였다(Table 1$)(\mathrm{p}<0.05)$.

$\mathrm{MG}-\mathrm{AB}$ 군은 $6.0 \pm 0.4 \mathrm{~cm}, \mathrm{MG}-\mathrm{ABL}$ 군은 $6.1 \pm 0.5 \mathrm{~cm}$ 로 종 균 $(\mathrm{A}, \mathrm{B}, \mathrm{L})$ 이 접종된 고추장을 섭취한 마우스들은 대장염 증상이 완화된 것을 관찰할 수 있었다. MG-AB군과 MG-ABL군은 대장의 길이가 control군과 비교하여 유의적 으로 증가된 것으로 나타났다( $\mathrm{p}<0.05)$. 한편 대장무게/길이 의 값은 normal군 $21.8 \pm 1.6 \mathrm{mg} / \mathrm{cm}$ 에 비해, control군은 $34.0 \pm 3.1 \mathrm{mg} / \mathrm{cm}$ 으로 normal군에 비해 유의적으로 높은 값 을 나타내었다 $(\mathrm{p}<0.05) . \quad M G-A B$ 군은 $31.7 \pm 3.2 \mathrm{mg} / \mathrm{cm}$, MG-ABL군은 $27.7 \pm 4.1 \mathrm{mg} / \mathrm{cm}$ 으로 고추장을 섭취한 마우 스의 대장길이/무게의 값이 감소된 것을 확인 할 수 있었다. 특히MG-ABL군은 control군에 비해 값이 유의적으로 감소 
하여 염증반응이 억제된 것을 확인하였다( $\mathrm{p}<0.05)$. 이러한 결과는 잡곡과 죽염, 종균 $(\mathrm{A}, \mathrm{B}, \mathrm{L})$ 을 접종한 고추장은 잡곡 중 보리의 항염증(10), 수수와 기장의 항산화(11,12) 효과와 죽염의 항염증(13) 효과로 인해 대장염을 억제한 것으로 생각되며, 더욱이 MG-ABL군은 MG-AB군에 비해 대장염 억제효과가 뛰어난 것으로 관찰되는데, 이는 $\mathrm{ABL}$ 내에 첨 가된 Lab. plantarum의 발효로 인한 발효산물들이 항산화 (17) 및 대장염 억제(23)를 더욱 증진시킨 결과라고 하겠다.

Table 1. Effects of Gochujang prepared with mixed grains, bamboo salt and Meju starters on the changes of body weight, colon length and colon weight/length mice with DSS-induced colitis

\begin{tabular}{cccc}
\hline Groups $^{1)}$ & Final body weight $(\mathrm{g})$ & Colon length $(\mathrm{cm})$ & $\begin{array}{c}\text { Colon length/weight } \\
(\mathrm{mg} / \mathrm{cm})\end{array}$ \\
\hline Normal & $20.4 \pm 1.0^{22)}$ & $7.5 \pm 0.4^{\mathrm{a}}$ & $21.8 \pm 1.6^{\mathrm{c}}$ \\
Control & $17.1 \pm 2.5^{\mathrm{b}}$ & $5.4 \pm 0.5^{\mathrm{c}}$ & $34.0 \pm 3.1^{\mathrm{a}}$ \\
(DSS) & $19.3 \pm 0.4^{\mathrm{a}}$ & $6.0 \pm 0.4^{\mathrm{b}}$ & $31.7 \pm 3.2^{\mathrm{a}}$ \\
MG-AB & $19.2 \pm 0.4^{\mathrm{a}}$ & $6.1 \pm 0.5^{\mathrm{b}}$ & $27.7 \pm 4.1^{\mathrm{b}}$ \\
\hline
\end{tabular}

${ }^{1)}$ Normal, no treatment; control 2.5\% DSS administration; MG-AB, $2.5 \%$ DSS+Gochujang prepared with mixed grain, bamboo salt and Meju starters (Asp. oryzae+Bac. subtilis) administration; MG-ABL, 2.5\% DSS+Gochujang prepared with mixed grain, bamboo salt and Meju starters (Asp. oryzae+Bac. subtilis+Lab. plantarum).

2k-c Means with the different letters in the same column are significantly different $(\mathrm{p}<0.05)$ by Duncan's multiple range test.

\section{전염증 사이토카인 IL-6의 함량}

혈청에서 IL-6 농도는 control군은 $90.5 \pm 3.4 \mathrm{pg} / \mathrm{mL}$ 로 normal군의 $38.3 \pm 0.8 \mathrm{pg} / \mathrm{mL}$ 에 비해 더 높은 IL-6의 농도를 나타내었다(Fig. 1)(p<0.05). 그러나 고추장을 섭취한 MG-

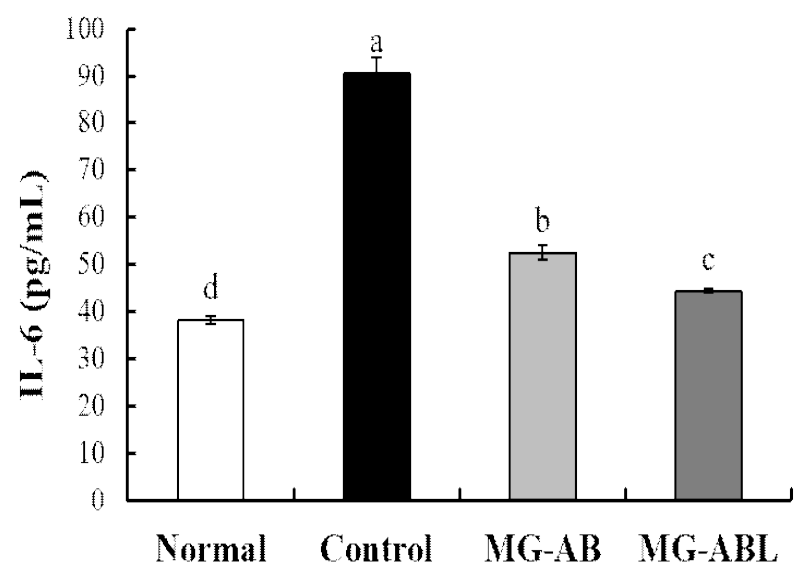

Fig. 1. Effects of Gochujang prepared with mixed grains, bamboo salt and Meju starters on serum pro-inflammatory cytokine(IL-6) in mice with DSS-induced colitis in mice.

Normal, no treatment; control 2.5\% DSS administration; MG-AB, 2.5\% DSS+Gochujang prepared with mixed grain, bamboo salt and Meju starters (Asp. oryzae+Bac. subtilis) administration; MG-ABL, $2.5 \%$ DSS+Gochujang prepared with mixed grain, bamboo salt and Meju starters (Asp. oryzae+Bac. subtilis+Lab. plantarum).

${ }^{\text {a.c }}$ Means with the different letters on the bar are significantly different $(\mathrm{p}<0.05)$ by Duncan's multiple range test.
$\mathrm{AB}$ 군은 $52.5 \pm 1.5 \mathrm{pg} / \mathrm{mL}, \mathrm{MG}-\mathrm{ABL}$ 군은 $44.4 \pm 0.5 \mathrm{pg} / \mathrm{mL}$ 로 control군에 비해 유의적으로 낮은 값을 나타내어 잡곡과 죽염, 종균을 접종한 메주로 담은 고추장이 염증반응을 억 제하는 것으로 나타났다( $\mathrm{p}<0.05)$. Jeong 등(24)의 연구에서 죽염과 종균을 접종한 메주로 담은 된장이 일반 메주로 담은 된장에 비해 항산화 및 대장암 억제효과가 높았는데, 본 연구에서 개발된 고추장도 메주에 종균발효와 죽염첨가 에 의해 이러한 효과가 나타난 것으로 생각된다. 특히 $\mathrm{MG}-\mathrm{ABL}$ 은 $\mathrm{MG}-\mathrm{AB}$ 군에 비해 유의적으로 낮은 $\mathrm{IL}-6$ 값을 나타내어 MG-ABL이 높은 항염증효과를 나타내었다 $(\mathrm{p}<0.05)$. IL-6는 NF-kB와 함께 암을 촉진시키는 인자이며, 대장염에서 대장암으로 발전할 때 중요한 관련 인자로 알려 져있다(25). Liu(4)의 연구에 의하면 마우스의 azoxymethane (AOM)/DSS로 유도한 대장암 모델에서 고추장이 마우스 혈청의 IL-6의 수준을 감소시킨 것으로 나타났는데, 이는 고추장에 다량으로 함유된 고추의 캡사이신 및 발효산물들 로 인해 염증반응을 억제시킨 것으로 생각되며(26), 본 연구 의 결과도 유사하게 나타난 것으로 사료된다. 종균을 접종 한 메주는 일반 메주에 비해 항산화 효과(15)가 증진되며, $\mathrm{AOM} / \mathrm{DSS}$ 로 유도한 마우스의 대장암 모델에서 IL-6의 수 준을 감소시켜(16), 메주의 종균 종류의 차이 특히 $L a b$. plantarum으로 인한 발효산물 및 발효조건의 변화에 의해 MG-ABL군이 MG-AB군에 비해 높은 항염증 효과를 나타 낸 것으로 생각된다.

대장조직에서 apoptosis 관련 유전자 $\mathrm{Bax}, \mathrm{Bcl}-2$ 의 mRNA 및 단백질 발현

Apoptosis 관련 인자인 Bax는 control군에 비해 고추장을 섭취한 군이 높고 $\mathrm{Bcl}-2$ 는 control군에 비해 고추장을 섭취 한 군이 낮아 개발된 종균 $(\mathrm{A}, \mathrm{B}, \mathrm{L})$ 을 접종한 잡곡 고추장을 섭취하게 되면 $\mathrm{Bax}$ 와 $\mathrm{Bcl}-2$ 의 $\mathrm{mRNA}$ 발현을 조절하여 마우 스의 대장조직에서 apoptosis를 유도하는 것으로 나타났다 (Fig. 2A). 특히 MG-ABL군은 Bax의 mRNA발현이 control 군에 비해 2 배 이상 발현되고, $\mathrm{MG}-\mathrm{AB}$ 군에 비해서도 유의 적으로 증가하고 $(\mathrm{p}<0.05), \mathrm{Bcl}-2$ 는 유의적으로 감소시켰다 $(\mathrm{p}<0.05)$. 단백질 발현 분석에서 $\mathrm{Bax}$ 는 control군에 비해 고추장을 섭취한 군(MG-AB, MG-ABL)이 2배 이상 높아지 고, $\mathrm{Bcl}-2$ 는 $\mathrm{MG}-\mathrm{AB}$ 군이 다소 증가했으나, $\mathrm{MG}-\mathrm{ABL}$ 군을 섭취한 군이 control군과 MG- $\mathrm{AB}$ 군에 비해 유의적으로 낮 아졌다(Fig. 2B). 따라서 개발된 고추장 특히 Lab. plantarum 이 첨가되어 발효된 고추장을 섭취하게 되면 Bcl-2의 발현 을 유의적으로 감소시켜 apoptosis를 유도하는 것으로 나타 났다. Fukata 등(27)은 DSS로 손상된 intestinal mucosal injury은 proliferation이 증가하고 apoptosis가 감소하는 것 으로 보고하였다. 염증반응이 발생하면 toll-like receptor 4(TLR4)를 조절하고, prostaglandin E2(PGE2)가 증가되어 대장세포의 증식을 더욱 일으키고, apoptosis를 감소시켜 
대장 내 조직의 암화를 촉진하는 것으로 알려져 있다 $(25,27)$. 본 연구에서는 고추장을 섭취한 마우스의 대장조 직에서 $\mathrm{Bax}, \mathrm{Bcl}-2$ 의 mRNA 및 단백질 발현이 조절되었는 데, Kim 등(26)의 연구에 의하면 capsaicin이 LPS로 유도된 macrophage의 염증반응을 억제하는 것으로 나타났으며, 한 편 $\mathrm{AOM} / \mathrm{DSS}$ 로 대장암을 유발시킨 마우스가 고추장을 섭 취하면 IL-6와 $\mathrm{Bcl}-2$ 를 감소시키고, $\mathrm{Bax}$ 를 증가시켜 염증을 억제하고 apoptosis를 촉진하는 것으로 보고되었다(4). 또한 $\mathrm{AOM} / \mathrm{DSS}$ 로 대장암을 유발시킨 마우스가 죽염(9회)을

\section{요 약}

$\mathrm{DSS}$ 로 대장염을 유도한 C57BL/6 마우스에게 잡곡(보리, 수수, 기장)과 죽염, 종균( $\mathrm{AB}, \mathrm{ABL})$ 을 접종한 메주로 만든 고추장을 섭취시켰다. $\mathrm{MG}-\mathrm{AB}$ 와 $\mathrm{MG}-\mathrm{ABL}$ 을 섭취한 마우 스는 control에 비교해 대장의 길이를 증가시키고, 무게/길 이비율은 감소시켜 대장염의 염증반응을 억제시켰다. MG-ABL은 혈청에서 IL-6의 발현을 control과 MG-AB군에 비해 유의적으로 감소시켰고, apoptosis 관련 인자인 $\mathrm{Bax}$

A.

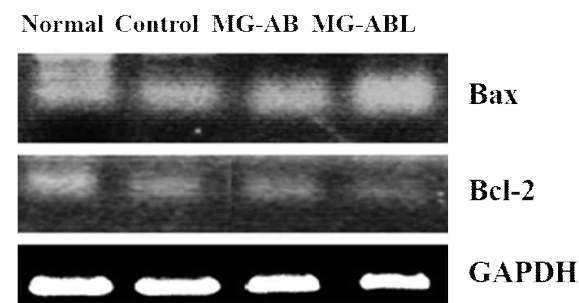

B.

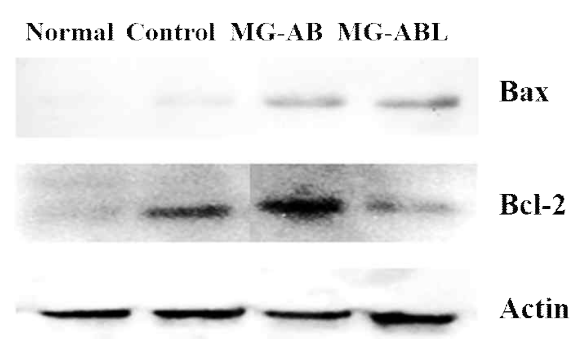

Bax

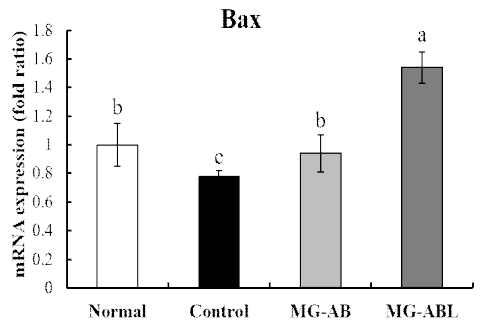

Bax

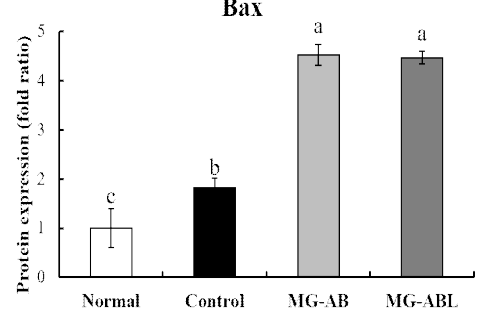

Bcl-2

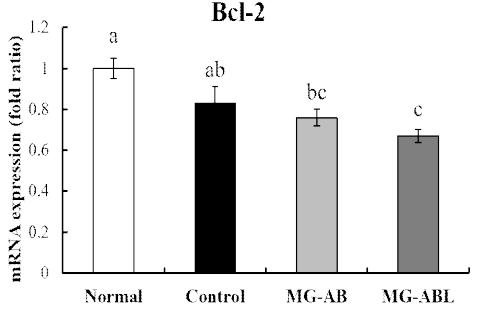

Bcl-2

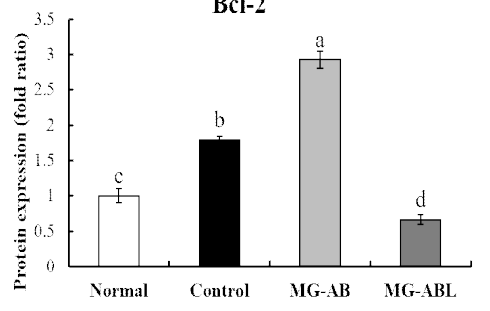

Fig. 2. Effects of Gochujang prepared with mixed grains, bamboo salt and Meju starters on colon tissue's mRNA (A) and protein (B) expression level of Bax, Bcl-2 in DSS-induced colitis in mice.

Normal, no treatment; Control 2.5\% DSS administration; MG-AB, 2.5\% DSS+Gochujang prepared with mixed grain, bamboo salt and Meju starters (Asp. oryzae+Bac. subtilis) administration; MG-ABL, 2.5\% DSS+Gochujang prepared with mixed grain, bamboo salt and Meju starters (Asp. oryzae+Bac. subtilis+Lab. plantarum).

Fold ratio: Gene expression/GAPDH or Actin $\times$ Normal numerical value.

(Normal fold ratio=1)

${ }^{a-d}$ Means with the different letters on the bars are significantly different $(p<0.05)$ by Duncan's multiple range test.

섭취하면 $\mathrm{Bax}$ 의 발현을 증가시키고 $\mathrm{Bcl}-2$ 의 발현을 감소시 켰으며(13), 동일한 모델에서 Asp. oryzae, Bac. subtilis로 발효시킨 메주는 일반 메주에 비해 항암효과가 높은 것으로 보고되었다(15). 따라서 이 연구에서 개발된 고추장은 DSS 로 damage를 입은 대장세포의 염증반응을 억제하고, 손상 된 대장세포는 apoptosis를 촉진하여, 대장염을 억제하는 효과가 있는 것으로 생각된다. 이와 더불어 $\mathrm{MG}-\mathrm{AB}$ 군에 비해 MG-ABL군의 대장염 억제 효과가 더욱 증진되었는 데, 이는 Lab. plantarum을 종균 $(\mathrm{A}, \mathrm{B}, \mathrm{L})$ 으로 접종하여 고추 장 제조에 사용하므로 유산균 자체의 활성효과와 유산균이 생성한 생리 기능성 발효산물 때문에 더욱 높은 대장염 억제 효과가 나타난 것으로 생각된다. 하지만 아직 유산균 의 어떠한 발효생성물과 probiotic 역할로 인해 이러한 결과 가 나타나는지에 대해 계속된 연구가 필요할 것으로 생각된 다.
와 Bcl-2의 발현을 조절하여 apoptosis를 유도하였다. 따라 서 $\mathrm{MG}-\mathrm{ABL}$ 은 발효 시 첨가된 Lab. plantarum로 인해 대장 조직의 손상을 억제하고 전염증성 사이토카인과 apoptosis 관련 인자를 조절하여 대장염을 억제하는 것으로 나타났 다.

\section{References}

1. Shin DH, Kim DH, Choi U, Lim DK, Lim MS (1996) Studies on the physicochemical characteristics of traditional Kochujang. Korean J Food Sci Technol, 28, 157-161

2. Shin DH, Kim DH, Choi U, Lim DK, Lim MS (1996) 
Studies on taste components of traditional Kochujang. Korean J Food Sci Technol, 28, 152-156

3. Rhee SH, Kong KR, Jung KO, Park KY (2003) Decreasing effect of Kochujang on body weight and lipid levels of adipose tissues and serum in rats fed a high-fat diet. J Korean Soc Food Sci Nutr, 32, 882-886

4. Lui FF (2015) Anti-obesity and colon cancer preventive effects of Kochujang in C57BL/6J mice. MS Thesis, Pusan National University, Korea, p. 63-72.

5. Lee HY, Bak SS, Moon SH, Kim SH, Park KY (2008) Fermentative characteristics, and antimutagenic and anticancer effects of Soonchang traditional Kochujangs. Cancer Prev Res, 13, 316-323

6. Oh YS, Baek JW, Park KY, Hwang JH, Lim SB (2013) Physicochemical and functional properties of Kochujang with broccoli leaf powder. J Korean Soc Food Sci Nutr, 42, 675-681

7. Cho HO, Kim JG, Lee HJ, Kang JH, Lee TS (1981) Brewing method and composition of traditional Kochuzang (red pepper paste) in Junrabook-do area. J Korean Agric Chem Soc, 24, 21-28

8. Park CH, Lee SK, Shin BK (1986) Effects of wheat flour and glutinous rice on quality of Kochujang. J Korean Agric Chem Soc, 29, 375-380

9. Kim DH, Yang SE, Rhim JW (2003) Fermentation characteristics of Kochujang prepared with various salts. Korean J Food Sci Technol, 35, 671-679

10. Kanauchi O, Nakamura T, Agata K, Mitsuyama K, Iwanaga $T$ (1998) Effects of germinated barley foodstuff on dextran sulfate sodium-induced colitis in rats. J Gastroenterol, 33, 179-188

11. Ra JE, Park JY, Seo WD, Sim EY, Ko JY, Nam MH, Han SI (2014) Antioxidative and anti-inflammatory activity of extract from milling by-products of sorghum cultivar, 'HwanggeumchaI. Korean J Crop Sci, 59, 463-469

12. Woo KS, Lee JS, Ko JY, Song SB, Seo HI, Seo MC, Oh BG, Kwak DY, Nam MH, Oh IS, Jeong HS (2012) Antioxidant compounds and antioxidant activities of different varieties of foxtail millet and proso millet according to cultivation time. J Korean Soc Food Sci Nutr, 41, 302-309

13. Zhao X (2011) Anticancer and antiinflammatory effects of bamboo salt and Rubus coreanus Miquel bamboo salt. $\mathrm{Ph}$ D Thesis, Pusan National University, Korea, p 43-58

14. Zhao X, Kim SH, Qi Y, Kim SY, Park KY (2012) Effects of different kinds of salt in the comutagenicity and growth of cancer cells. J Korean Soc Food Sci Nutr, 41, 26-32

15. Jeong JK (2012) Improvement of quality and probiotic effect of Meju and Doenjang prepared with mixed starter cultures. Ph D Thesis, Pusan National University, Korea, p $123-180$

16. Jeong JK, Chang HK, Park KY (2012) Inhibitory effects of Meju prepared with mixed starter cultures on azoxymethane and dextran sulfate sodium-induced colon carcinogenesis in mice. J Carcinog, 11, 30-38

17. Li S, Zhao Y, Zhang L, Zhang X, Huang L, Li D, Niu C, Yang Z, Wang Q (2012) Antioxidant activity of Lactobacillus plantarum strains isolated from traditional Chinese fermented foods. Food Chem, 135, 1914-1919

18. Wang K, Li W, Rui X, Chen X, Jiang M, Dong M (2014) Characterization of a novel exopolysaccharide with antitumor activity from Lactobacillus plantarum 70810 . Int J Biol Macromol, 63, 133-139

19. Park ES, Heo JH, Ju JH, Park KY (2016) Changes in quality characteristics of Gochujang prepared with different ingredients and meju Starters. J Korean Soc Food Sci Nutr, 45, 880-888

20. Bong YJ (2014) Probiotic effects of kimchi lactic acid bacteria $(\mathrm{LAB})$ and increased health functionality of baechu kimchi by LAB starters. MS Thesis, Pusan National University, Korea, p 30-85

21. Park EJ (2014) Increased health functionalities of ramyon that prepared with brown rice and sorghum flour added noodle and Doenjang bamboo salt soup. MS Thesis, Pusan National University, Korea, p 51-82

22. Aliakbarpour HR, Chamani M, Rahimi G, Sadeghi AA, Qujeq D (2012) The Bacillus subtilis and lactic acid bacteria probiotics influences intestinal mucin gene expression, histomorphology and growth performance in broilers. Asian-Australasian J Ani Sci, 25, 1285-1293

23. Duary RK, Bhausaheb MA, Batish VK, Grover S (2012) Anti-inflammatory and immunomodulatory efficacy of indigenous probiotic Lactobacillus plantarum Lp91 in colitis mouse model. Mole Biol Report, 39, 4765-4775

24. Jeong MW, Jeong JK, Kim SJ, Park KY (2013) Fermentation characteristics and increased functionality of Doenjang prepared with bamboo salt. J Korean Soc Food Sci Nutr, 42, 1915-1923

25. Bromberg J, Wang TC (2009) Inflammation and cancer: IL-6 and STAT3 complete the link. Cancer Cell, 15, 79-80

26. Kim CS, Kawada T, Kim BS, Han IS, Choe SY, Kurata T, Yu R (2003) Capsaicin exhibits anti-inflammatory property by inhibiting IkB-a degradation in LPS- 
stimulated peritoneal macrophages. Cell Signaling, 15, 299-306

27. Fukata M, Chen A, Klepper A, Krishnareddy S, Vamadevan AS, Thomas LS, Xu R, Inoue H, Arditi M,
Dannenberg AJ, Abreu MT (2006) Cox-2 is regulated by toll-like receptor-4 (TLR4) signaling: role in proliferation and apoptosis in the intestine. Gastroenterol, $131,862-877$ 